\title{
Secondary Market Liquidity and Primary Market Pricing of Corporate Bonds ${ }^{\dagger}$
}

\author{
Michael A. Goldstein ${ }^{1}$, Edith S. Hotchkiss ${ }^{2, *}$ and David J. Pedersen ${ }^{3}$ \\ 1 Babson College, 320 Tomasso Hall, Babson Park, MA 02457, USA; goldstein@babson.edu \\ 2 Boston College, Fulton Hall, Room 340, Chestnut Hill, MA 02467, USA \\ 3 Rutgers School of Business-Camden, 227 Penn Street, Camden, NJ 08102, USA; david.pedersen@rutgers.edu \\ * Correspondence: hotchkis@bc.edu \\ + An earlier version of this paper entitled "Liquidity and the Pricing of Corporate Bond Issues" was presented \\ at the 2009 Financial Management Association Annual Meeting.
}

Received: 14 February 2019; Accepted: 3 May 2019; Published: 13 May 2019

check for updates

\begin{abstract}
This paper studies the link between secondary market liquidity for a corporate bond and the bond's yield spread at issuance. Using ex-ante measures of expected liquidity at the time of issuance, based on the characteristics of the underwriting syndicate, we find an economically large impact of liquidity on yield spreads. We estimate that a $10 \%$ increase in expected liquidity implies a decrease in the yield spread at issuance of between $8 \%$ and $14 \%$. Our results suggest that liquidity has an important effect on firms' cost of capital, and they contribute to the literature which examines the impact of liquidity on asset prices.
\end{abstract}

Keywords: corporate bonds; liquidity; primary market pricing

\section{Introduction}

Does liquidity affect asset pricing? This question is important for academics, investors, and corporate issuers. Theoretical models, such as Amihud and Mendelson (1986), suggest that assets with low liquidity require a liquidity premium, but the magnitude of these premia is debatable. More recently, Acharya and Pedersen (2005) demonstrate that a security's required return depends in part on its expected liquidity. Previous empirical studies mostly focus on equity markets and find that the systematic component of liquidity appears to be priced in the cross-section of equity returns. These studies examine different aspects of liquidity or some common factor using measures of transactions costs such as bid-ask spreads, measures of price impact, or measures of trading activity such as volume.

In this paper, we study the link between secondary market liquidity in corporate bonds and the bond's yield spread at issuance. Using ex-ante measures of expected liquidity at the time of issuance based on characteristics of the underwriting syndicate, we find an economically large impact of expected liquidity on offering yield spreads. Our results suggest that secondary market liquidity has an important effect on firms' cost of capital and provide further evidence of the links between liquidity and asset pricing.

The corporate bond market offers an intriguing opportunity to examine the pricing of liquidity. Corporate bonds primarily trade over-the-counter (OTC) in a dealer market, in which investors rely on dealers to facilitate trades and foster a liquid market. The relative paucity of trading in some bonds imposes significant inventory risk on dealers. Trading activity varies considerably across issues with a substantial portion of bonds in the market trading infrequently or not at all. In addition, dealers in this market are not homogenous and may differ in important dimensions such as capital constraints 
and tolerance for inventory risk. As a result, dealers may differ in their ability to commit to providing liquidity to the secondary market for a specific bond.

Although it is a decentralized dealer market, we are able to observe prices and volumes for all transactions in U.S. corporate bonds since July 2002 when TRACE (Trade Reporting and Compliance Engine) was implemented and post-trade dissemination started. ${ }^{1}$ Bao et al. (2011), Chen et al. (2007), and Dick-Nielsen et al. (2012), among others, relate measures of secondary market liquidity to secondary market yield spreads on corporate bonds, and find mixed results depending on the measures used. Overall, there is evidence that while some liquidity measures, such as bid-ask spreads and price impact (Amihud 2002), are priced in bond yields observed in the secondary market, direct measures of trading activity such as trade count and volume are not.

In contrast to the prior literature, this paper focuses on the impact of liquidity on pricing in the primary market for corporate bonds. ${ }^{2}$ Specifically, we test whether expected secondary market liquidity is related to offering price and yields. Underwriters provide services to the issuing company both in selling the issue and in providing liquidity in the aftermarket. Thus, aftermarket liquidity can have an important impact on the proceeds the issuing firm can raise and can affect the company's access to capital. ${ }^{3}$ Our results suggest expected liquidity directly affects the future cash flows of the firm.

Our sample consists of 5283 investment grade and high yield bonds issued between January 2012 and December 2017. Since July 2002, all secondary market trades in corporate bonds in the U.S. are reported to the Financial Industry Regulatory Authority (FINRA) through the TRACE system. Since March 2010, primary market trades are also reported to TRACE; thus, dealers we observe reporting primary market sales can be assumed to be members of the underwriting syndicate. In order to calculate trading characteristics (specifically, centrality) of the dealers acting as underwriters in the calendar year prior to the offering, we limit our sample period to bonds issued in 2012 or later.

We first consider simple OLS regressions relating the yield spread at offering (relative to a benchmark treasury) to different ex-post measures of realized secondary market trading activity, as well as to control variables shown in prior literature as determinants of corporate bond yields. Consistent with the prior literature, we examine several measures of corporate bond liquidity realized in the one or two month window following the offering: the number of days when a dealer buys from a customer (days traded); the number of trades in which a dealer buys from a customer (trade count); the proportion of trading volume where dealers quickly offset a bond purchase with a matching quantity sell trade (riskless volume), which measures the extent to which dealers trade without committing overnight capital; and median realized trading costs of dealer round-trip trades (round-trip spreads).

The OLS regressions produce somewhat conflicting results depending on the measure of realized trading - higher trading activity (days traded and trade count) is associated with higher yield spreads at offering, as is a greater proportion of riskless trades and higher round-trip spreads. These results, in particular for the first two measures, may be problematic to interpret. One problem is that information released prior to the offering or some other unobservable characteristic of the issuer might also affect trading in the aftermarket, leading to a spurious correlation (either positive or negative) between the offering yield spread and trading activity. A second problem, as noted in prior literature, is that different measures of trading activity may capture different aspects of market liquidity.

To model expected liquidity at the time of issuance, we consider an alternative instrumental variables (IV) approach. Based on recent literature describing the core-periphery network structure of over-the-counter bond markets (including Di Maggio et al. 2017; Hollifield et al. 2017; Li and Schürhoff

1 See Goldstein and Hotchkiss (2012) for a timetable of the phase-in of dissemination under TRACE.

2 Ellul and Pagano (2006) provide a theoretical model that relates initial public offering (IPO) underpricing to an asset's expected liquidity. The authors posit that an increase in expected liquidity leads to an increase in the offer price for the asset. Adapting this framework to the primary market for corporate bonds, if investors value liquidity, bonds with higher expected liquidity should have higher offer prices and thus lower offering yield spreads.

3 Benveniste and Singh (1993) and Lemmon and Roberts (2010) describe the impact of secondary market liquidity provided by Drexel Burnham Lambert for bonds it underwrote on firms' ability to issue high yield bonds. 
2019), we use the maximum eigenvector centrality of dealers in the underwriting syndicate as our instrument since the existence of a well-connected dealer in the underwriting syndicate suggests a greater ability of the dealer to make a market in that bond. Consistent with these expectations, our first stage regressions confirm that the network centrality of underwriters is a strong predictor of realized secondary market liquidity for the first three measures (days traded, trade count, and riskless volume) of realized trading. ${ }^{4}$

The second stage regressions, using the instrumented values of the realized trading measures, produce consistent results demonstrating a significant negative relationship between expected secondary market liquidity and yield spreads at offering. The results continue to hold in subsamples by rating categories (investment grade versus high yield) and within the subsample where riskless volume is unlikely to be mis-measured (bonds rated BBB+ and below). The key challenge to our IV approach is whether the exclusion restriction is violated-specifically, whether the dealer's network centrality impacts yield spread at issuance through channels other than through the bond's expected liquidity. The most obvious potential violation is that underwriter reputation is related both to centrality and the yield spreads an underwriter achieves for its client issuers, possibly through a matching of underwriters with issuers of a certain quality. Dealer fixed effects can control for time invariant dealer quality, though more granular fixed effects weaken the power of our instrument. Interpreting our IV results with fixed effects with some caution, we continue to find that our instrumented variable is related to offering yield spreads, consistent with our baseline results. We also show that dealer centrality varies little over longer time periods, and that our baseline results hold for sample subperiods (as well as subsamples by issuer rating quality, as noted above). Combined, these results cannot eliminate, but do alleviate, the concern that a correlation between dealer centrality and the quality of an underwriter invalidates our instrument.

Overall, our results show the importance of the link between secondary market activity and the pricing of corporate bonds at issuance. Our work complements earlier research demonstrating the pricing of liquidity measures in corporate bonds using secondary market data from TRACE, but focuses on the link to the primary market which is of clear importance to issuers. ${ }^{5}$ A further advantage of using primary market yields to understand the pricing of liquidity is that the yield at offering is directly observable, and is not subject to the measurement problems due to the substantial price dispersion in the secondary market trades (Goldstein and Hotchkiss 2012).

Our paper is also related to several studies that focus on underpricing in the issuance of corporate bonds. These papers examine the determinants of underpricing (Datta et al. 1997, 2000; Cai et al. 2007) and demonstrate greater underpricing for mega-bonds (Helwege and Wang 2017). Goldstein and Hotchkiss (2012) and Brugler et al. (2018) examine the link between underpricing and post-trade transparency under TRACE. Finally, our work is related to two recent papers that examine allocation decisions of underwriters (Nikolova et al. 2019; Flanagan et al. 2019) and examine the relationship between holdings of institutional investors and underpricing of corporate bonds (Nagler and Ottonello 2018).

The remainder of this paper proceeds as follows. Section 2 provides an overview of our data and sample. Section 3 reports OLS regressions relating yield spreads at issuance to measures of secondary market trading activity. Section 4 reports our alternative IV models, using network centrality of syndicate dealers as the instrument, and considers the robustness of our results to selection of dealers into syndicates. Section 5 concludes.

4 Goldstein and Hotchkiss (2019) point out the difficulties in interpreting round-trip spreads when a larger proportion of trades are completed as essentially "riskless" trades, where the dealer quickly offsets bond purchases and does not assume inventory risk. Spreads on these riskless trades are significantly lower, even for lower grade bonds and for bonds which trade very infrequently.

5 Field et al. (2018) show that an issuer's lower cost of capital is associated with increases in capital expenditures and acquisition activity. 


\section{Data and Sample Construction}

Our initial sample of newly issued bonds consisted of 6782 corporate bonds issued between January 2012 and December 2017, as reported in Mergent's Fixed Income Securities Database. We required bonds to be fixed rate and non-convertible and to have secondary market trades reported to TRACE in the first month following the offering date. For 5283 of these bonds, Mergent reports the yield spread over a benchmark treasury at issuance. Our regulatory TRACE dataset included anonymous dealer identifiers. During our sample period, dealers were required to report certain primary market trades to TRACE, which enabled us to infer which dealers were members of the underwriting syndicate. ${ }^{6}$ The bonds in our sample had, on average, 3.6 dealers reporting primary market trades to TRACE.

Table 1 contains a list and the definitions of the variables we employ. Since Mergent does not report the treasury yield spread for all bonds, a comparison of characteristics of the bonds used in our analysis with those for which treasury spread data is not reported is provided in Table 2. Offering amounts were not statistically different, with a mean offering size of $\$ 704$ million for bonds with information available for their yield spread at issuance. Bonds on average had approximately 11 years to maturity, and approximately one third of the sample consisted of 144A bonds, which are predominantly high yield issues. We used these bond characteristics as control variables in our regressions explaining yields at issuance.

Table 1. Variable definitions.

\begin{tabular}{|c|c|}
\hline Variable Name & Definition \\
\hline Offering yield spread & Yield spread over a comparable maturity treasury at offering. \\
\hline Issue size & Offering amount (\$ millions) \\
\hline Maturity & Number of days between the issue's maturity date and its offering date. \\
\hline Rule $144 \mathrm{~A}$ & Indicator variable equal to one for $144 \mathrm{~A}$ issues, and zero otherwise. \\
\hline Rating FE & $\begin{array}{l}\text { Fixed effects for credit rating, using lowest credit rating of Moody's, S\&P, or Fitch } \\
\text { based on the issue's initial rating. }\end{array}$ \\
\hline Days traded & $\begin{array}{l}\text { Number of days when the new issue has at least one trade in which a dealer is } \\
\text { buying from a customer during the } 1(2) \text { months after the offering }\end{array}$ \\
\hline Days traded $(\geq 100)$ & $\begin{array}{l}\text { Number of days when the new issue has at least one trade (of at least } 100 \text { bonds) } \\
\text { in which a dealer is buying from a customer during the } 1 \text { (2) months after the } \\
\text { offering }\end{array}$ \\
\hline Trade count & $\begin{array}{l}\text { Number of trades in which a dealer is buying from a customer during the } 1 \text { (2) } \\
\text { months after the offering. }\end{array}$ \\
\hline Trade count $(\geq 100)$ & $\begin{array}{l}\text { Number of trades (of } 100 \text { bonds or more) in which a dealer buys from a customer } \\
\text { during the } 1(2) \text { months after the offering. }\end{array}$ \\
\hline Riskless volume & $\begin{array}{l}\text { Percent of volume related to riskless trades based on round-trip transactions of } \\
\text { less than five days. Riskless trades are instances of a buy and sell trade for a given } \\
\text { bond of the same quantity, from the same dealer, and within the same day. }\end{array}$ \\
\hline Round-trip spread & $\begin{array}{l}\text { Difference of the dealer's buy price and weighted average sell price using the } \\
\text { trades identified as part of a dealer round-trip. }\end{array}$ \\
\hline UW centrality & $\begin{array}{l}\text { Maximum eigenvector dealer centrality across the dealers in the issue's } \\
\text { underwriting syndicate based on secondary market trading in the calendar year } \\
\text { prior to the offering }\end{array}$ \\
\hline Underwriter FE & $\begin{array}{l}\text { Fixed effect for the top } 20 \text { underwriters. Top } 20 \text { underwriters are those with the } \\
\text { highest aggregate primary market trade volume across all offerings in our sample. }\end{array}$ \\
\hline
\end{tabular}

6 The identity of anonymous dealers reporting primary market trades (thereby assumed to be syndicate members) is not provided in the TRACE data. 
Table 2. New Issues Sample Description.

\begin{tabular}{|c|c|c|c|}
\hline & $\begin{array}{c}\text { New Issues with } \\
\text { Treasury Spread Data }\end{array}$ & $\begin{array}{l}\text { New Issues without } \\
\text { Treasury Spread Data }\end{array}$ & Difference \\
\hline Number of observations & 5283 & 1499 & \\
\hline Offering amount & $\$ 704,136$ & $\$ 673,931$ & $\$ 30,205$ \\
\hline Years to maturity & 11.4 & 10.5 & $0.9^{* * *}$ \\
\hline $144 \mathrm{~A}$ & $33.50 \%$ & $47.90 \%$ & $-4.40 \% * * *$ \\
\hline Callable & $95.20 \%$ & $92.70 \%$ & $2.50 \% * * *$ \\
\hline High yield & $26.20 \%$ & $43.70 \%$ & $-17.50 \%$ *** \\
\hline Days with trades (6 months) & 61.6 & 57.5 & $4.1^{* * *}$ \\
\hline Number of trades (6 months) & 171.3 & 169 & 2.3 \\
\hline Riskless volume (6 months) & $37.10 \%$ & $41.90 \%$ & $-4.80 \% * * *$ \\
\hline Median spread (6 months) & 0.026 & 0.028 & -0.003 \\
\hline \multicolumn{4}{|l|}{ Issue Year: } \\
\hline 2012 & $21.3 \%$ & & \\
\hline 2013 & $15.3 \%$ & & \\
\hline 2014 & $11.4 \%$ & & \\
\hline 2015 & $13.9 \%$ & & \\
\hline 2016 & $17.4 \%$ & & \\
\hline 2017 & $20.7 \%$ & & \\
\hline
\end{tabular}

We used TRACE data to compute four measures of realized secondary market trading, each over horizons of one, two, and three months following the offering date: days traded, trade count, riskless volume, and round-trip spread. We computed days traded as the number of days when the new issue had at least one secondary market trade of any size; we included only trades where a dealer was buying from a customer, to reflect the investor's ability to sell bonds after the offering. Trade count was computed as the number of trades (of any size) in which a dealer buys from a customer. We also considered the robustness of our results to computing these two measures using only trades of at least 100 bonds, which eliminated the majority of retail-sized trades (Goldstein et al. 2007).

Trading consists of transactions where dealers take on principal risk as well as shorter term round-trip trades where dealers act more as brokers. We followed the methodology of Goldstein and Hotchkiss (2019) to identify three types of "dealer round-trips", matching buys and sells of a dealer in a given bond that are likely related. First, we identified all instances of a buy and sell trade for a given bond of the same quantity, from the same dealer, and within the same day, which we refer to as riskless trades. ${ }^{7}$ These riskless trades are completed in the same day and do not require notable contribution of dealer capital overnight. Second, we identify instances where a dealer's buy trade is broken into more than one sale on the same day, by matching the buy trade with two or more sells with total quantity up to the amount of the buy trade. Third, using all remaining transactions, we followed transactions in time order for up to 60 days following a dealer buy to locate sells of the same dealer and same bond, cumulating up to the quantity of the initial buy. Based on the round-trips we identified, we computed riskless volume as the percent of volume related to riskless trades based on round-trip transactions of less than five days. We also calculated dealers' round-trip spread as the difference in the dealer's buy price and weighted average sell price using the trades identified as part of a round-trip. ${ }^{8}$

Underwriters in the syndicate often play an active role in the aftermarket trading of a new issue. The prominence of underwriters is not surprising given an underwriter's informational advantage

7 This method is closest to that of "paired trades" in Zitzewitz (2010) and Sirri (2014) and "riskless principal trades" in Ederington et al. (2014), Harris (2015), and Schultz (2017). See Goldstein and Hotchkiss (2019) for additional details of this procedure.

8 Goldstein and Hotchkiss (2019) show that interpretation of spreads is confounded by differences in the trading activity of bonds, in that less actively traded bonds trades are more likely to have riskless round-trips completed at lower spreads than similar but actively traded bonds. We provide further discussion along with our IV results. 
over dealers that did not serve in the syndicate. Goldstein and Hotchkiss (2012) report that in the first month following the offering, dealers that served in the syndicate execute over half of all customer volume, and that syndicate dealers remain active throughout the first six months of trading. Our TRACE data provides anonymous dealer identifiers, but unlike data from earlier periods also includes primary market trades. We can assume that any dealer with primary market trades for a given bond is a member of the underwriting syndicate for that bond. Following Goldstein and Hotchkiss (2019), we computed the eigenvector centrality of all dealers in the TRACE dataset using all secondary market trades of each dealer. ${ }^{9}$ For each new issue, dealer centrality is the maximum centrality across all dealers with primary market trades in that bond, using eigenvector centrality based on trades in the calendar year preceding the offering. We also create underwriter fixed effects for the 20 dealers with the highest aggregate primary market trade volume across all offerings in our sample.

\section{Determinants of Yield Spread at Issuance: OLS Results}

We first examine OLS regressions, where the dependent variable is the yield spread at issuance. We controlled for bond characteristics, as described above, used in related literature to explain corporate bond yield spreads. ${ }^{10}$ We further included fixed effects for rating categories and by year.

Table 3 reports the OLS regression results, using variables for the realized secondary market trading in the one- and two-month periods following the issue date (results are nearly identical using a longer horizon to measure realized trading). The coefficients for the trading variables are each strongly significant, but their interpretations differ. Regressions 1 and 2 ( 3 and 4) show that yield spreads at issuance are significantly greater when there is higher post-offering trading activity, measured by days traded (customer trade count). However, interpretation of these results may be problematic since shocks affecting the pricing of the new issue might also impact trading activity in the aftermarket.

Table 3. Offering Yield Spread and Realized Secondary Market Trading (OLS).

\begin{tabular}{|c|c|c|c|c|c|c|c|c|}
\hline \multirow{2}{*}{$\begin{array}{l}\text { Trading } \\
\text { Measure: }\end{array}$} & \multicolumn{2}{|c|}{ Days Traded } & \multicolumn{2}{|c|}{ Trade Count } & \multicolumn{2}{|c|}{ Riskless Volume } & \multicolumn{2}{|c|}{ Roundtrip Spread } \\
\hline & (1) & (2) & (3) & (4) & (5) & (6) & (7) & (8) \\
\hline Trading (1 mo) & $\begin{array}{c}0.0851 \text { *** } \\
(0.026)\end{array}$ & & $\begin{array}{c}0.0945^{* * * *} \\
(0.016)\end{array}$ & & $\begin{array}{c}0.193 * * * \\
(0.040)\end{array}$ & & $\begin{array}{c}0.521^{* * * *} \\
(0.128)\end{array}$ & \\
\hline Trading (2 mo) & & $\begin{array}{c}0.0890^{* * * *} \\
(0.024)\end{array}$ & & $\begin{array}{c}0.104^{* * *} \\
(0.017)\end{array}$ & & $\begin{array}{c}0.170 * * * \\
(0.040)\end{array}$ & & $\begin{array}{c}0.482 * * * \\
(0.132)\end{array}$ \\
\hline $\ln ($ issue size) & $\begin{array}{c}0.0686^{* * * *} \\
(0.021)\end{array}$ & $\begin{array}{c}0.0778^{* * * *} \\
(0.022)\end{array}$ & $\begin{array}{c}0.116^{* * *} \\
(0.022)\end{array}$ & $\begin{array}{c}0.128^{* * *} \\
(0.023)\end{array}$ & $\begin{array}{l}0.0161 \\
(0.016)\end{array}$ & $\begin{array}{l}0.0131 \\
(0.016)\end{array}$ & $\begin{array}{l}0.0117 \\
(0.016)\end{array}$ & $\begin{array}{l}0.0106 \\
(0.016)\end{array}$ \\
\hline $\ln$ (maturity) & $\begin{array}{c}0.218^{* * *} \\
(0.015)\end{array}$ & $\begin{array}{c}0.220 * * * \\
(0.015)\end{array}$ & $\begin{array}{c}0.201 \text { *** } \\
(0.014)\end{array}$ & $\begin{array}{c}0.205^{* * *} \\
(0.014)\end{array}$ & $\begin{array}{c}0.220 * * * \\
(0.015)\end{array}$ & $\begin{array}{c}0.222 * * * \\
(0.015)\end{array}$ & $\begin{array}{c}0.215^{* * * *} \\
(0.015)\end{array}$ & $\begin{array}{c}0.217 * * * \\
(0.015)\end{array}$ \\
\hline Rule $144 \mathrm{~A}$ & $\begin{array}{c}0.388^{* * * *} \\
(0.029)\end{array}$ & $\begin{array}{c}0.391 * * * \\
(0.028)\end{array}$ & $\begin{array}{c}0.389 * * * \\
(0.028)\end{array}$ & $\begin{array}{c}0.393^{* * *} \\
(0.028)\end{array}$ & $\begin{array}{c}0.373 * * * \\
(0.028)\end{array}$ & $\begin{array}{c}0.374 * * * \\
(0.029)\end{array}$ & $\begin{array}{c}0.368^{* * *} \\
(0.028)\end{array}$ & $\begin{array}{c}0.370 * * * \\
(0.029)\end{array}$ \\
\hline Callable & $\begin{array}{l}0.0451 \\
(0.047)\end{array}$ & $\begin{array}{c}0.042 \\
(0.047)\end{array}$ & $\begin{array}{l}0.0621 \\
(0.046)\end{array}$ & $\begin{array}{l}0.0565 \\
(0.045)\end{array}$ & $\begin{array}{l}0.0226 \\
(0.049)\end{array}$ & $\begin{array}{c}0.018 \\
(0.049)\end{array}$ & $\begin{array}{c}0.03 \\
(0.048)\end{array}$ & $\begin{array}{l}0.0258 \\
(0.047)\end{array}$ \\
\hline Constant & $\begin{array}{c}4.181^{* * *} \\
(0.282)\end{array}$ & $\begin{array}{c}3.099 * * * \\
(0.278)\end{array}$ & $\begin{array}{c}4.814^{* * *} \\
(0.315)\end{array}$ & $\begin{array}{c}3.762 * * * \\
(0.295)\end{array}$ & $\begin{array}{c}3.511^{* * * *} \\
(0.258)\end{array}$ & $\begin{array}{c}2.376^{* * * *} \\
(0.244)\end{array}$ & $\begin{array}{c}3.581^{* * * *} \\
(0.258)\end{array}$ & $\begin{array}{c}2.452^{* * *} \\
(0.246)\end{array}$ \\
\hline Observations & 5283 & 5254 & 5283 & 5254 & 5283 & 5254 & 5283 & 5254 \\
\hline R-squared & 0.686 & 0.686 & 0.689 & 0.69 & 0.687 & 0.686 & 0.686 & 0.686 \\
\hline Rating FE & Yes & Yes & Yes & Yes & Yes & Yes & Yes & Yes \\
\hline Year FE & Yes & Yes & Yes & Yes & Yes & Yes & Yes & Yes \\
\hline
\end{tabular}

The table reports OLS regressions in which the dependent variable is the natural log of the treasury spread at offering of bonds issued between 2012 and 2017. The explanatory variables of interest are measures of secondary market trading in the one-month or two-month period following the offering date. All variables are as defined in Table 1. All models include credit rating fixed effects, based on the issue's initial rating, and year fixed effects. Standard errors clustered at the issuer level are shown in parentheses. ${ }^{* * *}$ indicate coefficients significant at the $1 \%$ levels, respectively.

9 See also Di Maggio et al. (2017), Hollifield et al. (2017), Li and Schürhoff (2019), and other papers regarding use of network measures in over-the-counter bond markets.

10 Prior literature suggests that a bond's credit rating, amount outstanding, and maturity all covary with the bond's liquidity (see Chen et al. 2007; Bao et al. 2011; and Nashikkar et al. 2011). In addition, 144A private placements and callable bonds may each have different levels of secondary market liquidity. Therefore, our regressions control for these bond characteristics, along with rating and year fixed effects. Controlling for the issuer's industry (not reported) produces similar results. 
The OLS results using days traded and trade count also do not appear consistent with those shown in Regressions 5 and 6 using riskless volume; when there is a greater proportion of riskless volume, meaning dealers take a smaller proportion of secondary market trading volume into inventory, yield spreads are higher. This is consistent with the interpretation of greater dealer risk, as well as investor risk, in holding these bond issues being reflected in the yield at issuance. Similarly, Regressions 7 and 8 show that higher round-trip spreads are associated with a higher yield spread at issuance.

The control variables have signs as expected and vary in economic importance. Larger issues command higher yields, ${ }^{11}$ while longer maturity and Rule $144 \mathrm{~A}$ bonds are also issued at higher spreads. Other characteristics, such as seniority or security, are not included but do not affect our results, and are reflected in the rating category fixed effects.

Overall, the OLS results do not provide a clear picture relating secondary market realized trading and yield spreads at issuance. In addition to endogeneity concerns, two other factors may explain the arguably counter-intuitive results for the first two measures of realized liquidity. One, as pointed out in an extensive literature (see for example Johnson 2008), is that different measures of trading activity behave differently and capture different aspects of liquidity. The second is that the relevant measure for pricing to investors at the time of issuance is the expected, rather than the realized, secondary market liquidity. The observed measures of realized secondary market liquidity may not be suitable proxies for expected liquidity in our yield spread models.

\section{Determinants of Yield Spread at Issuance: IV Results}

Our mixed results relating offering yield spreads and various trade-based measures of secondary market liquidity are consistent with results in the existing literature (see for example, Dick-Nielsen et al. 2012). Econometrically, our trade-based measures are endogenously determined with the yield spread because of both omitted variables (i.e., variables that jointly cause offering yields and liquidity) and reverse causality (i.e., a shock to the offering yield spread that leads to a change in liquidity). To isolate the variation in offering spreads due to the liquidity component of the trade-based measures, we implement an instrumental variable (IV) approach using the centrality of the dealers in the underwriting syndicate as our instrument. The following equations present a generalization of our IV model:

$$
\begin{gathered}
\text { Liquidity }_{i}=\pi U W \text { centrality }_{i}+\varphi \text { Controls }_{i}+\omega_{\text {Rating }}+\tau_{\text {Year }}+\eta_{i} \\
\text { Offering Spread }_{i}=\beta^{I V} \text { Liquidity }_{i}+\gamma \text { Controls }_{i}+v_{\text {Rating }}+\psi_{\text {Year }}+\varepsilon_{i}
\end{gathered}
$$

We measure underwriter centrality (UW centrality) using the maximum eigenvector dealer centrality across all dealers in the issue's syndicate, using trades in the calendar year prior to the offering. For this to be a valid instrument, it must both be relevant $\left(\operatorname{cov}\left(U W\right.\right.$ centrality $_{i}$, Liquidity $\left.\left._{i}\right) \neq 0\right)$ and satisfy the exclusion restriction $\left(\operatorname{cov}\left(U W\right.\right.$ centrality $\left.\left._{i}, \varepsilon_{i}\right)=0\right) .{ }^{12}$

While we will formally test for the relevancy of the instrument, there is good reason to believe the structure of the syndicate impacts secondary market trading. Given the importance of syndicate dealers in making markets for new issues, the expected liquidity of a new issue corporate bond is likely a function of the market making capability of the dealers in the syndicate. All else being equal, securities issued by syndicates comprised of dealers that demonstrate an ability to foster a liquid market will have a higher level of expected liquidity than those brought to market by syndicates of lesser ability. For corporate bonds issued in 2011 and earlier, Goldstein and Hotchkiss (2012) show

11 This result is consistent with Helwege and Wang (2017), who find that that "mega-bonds" have high liquidity, but their yields are actually higher at issuance than smaller issue sizes.

12 We do not report $\mathrm{R}^{2}$ with our IV results. Scribney et al. (2019) explain: “The model's residuals are computed over a set of regressors different from those used to fit the model. This means a constant-only model of the dependent variable is not nested within the two-stage least-squares model, even though the two-stage model estimates an intercept, and the residual sum of squares (RSS) is no longer constrained to be smaller than the total sum of squares." 
that the issue's lead underwriters have the highest level of customer volume in each of the first six months of trading, and this result is even stronger for high-yield bonds. Several other recent studies demonstrate the importance of dealer centrality to liquidity in the core-periphery network structure of the OTC corporate bond market (see for example, Di Maggio et al. 2017).

Since we cannot formally test the exclusion restriction, the validity of our instrument rests on the belief that, conditional on the control variables in the model, underwriter centrality only impacts the offering yield through its effect on the bond's secondary market liquidity. To rule out contemporaneous market effects and allow for each market maker's ability to evolve through time, we measure dealer centrality using trading data from the calendar year prior to offering date. After controlling for the explanatory variables in the model, there appear to be few direct channels through which the centrality of the new issue's syndicate impacts the offering's yield spread. We first present baseline IV results which assume the exclusion restriction holds, and then further discuss potential violations of the exclusion restriction below.

Results for the IV model are reported in Table 4 using days traded (Panel A), trade count (Panel B), and riskless volume (Panel C) to measure realized secondary market trading. ${ }^{13}$ From the first-stage model in each case, we test whether our instrument is relevant. A natural inclination is to test whether the coefficient on the instrument in Equation (1) is significantly different from zero (from Equation (1), $\pi=0$ ). UW centrality is strongly positive and significant for days traded and trade count, indicating that underwriter centrality is a strong predictor of higher secondary market trading activity. The significant negative relationship between UW centrality and riskless volume is consistent with the interpretation in Goldstein and Hotchkiss (2019) that a lower incidence of riskless trades occurs when dealers are more willing or able to provide liquidity. The coefficient for round-trip spread (not reported) is insignificant; we do not report this analysis because, as discussed above, Goldstein and Hotchkiss (2019) show that interpretation of spreads without further modeling is problematic when a significant portion of trades are "riskless" paired trades where dealers immediately offset bond purchases and do not take on inventory risk.

Table 4. IV Regressions for Offering Yield Spread.

\begin{tabular}{|c|c|c|c|c|}
\hline \multirow[t]{2}{*}{ A. Days Traded } & \multicolumn{2}{|c|}{ (1) } & \multicolumn{2}{|c|}{ (2) } \\
\hline & 1st stage & 2nd stage & 1st stage & 2nd stage \\
\hline UW centrality & $\begin{array}{c}4.695^{* * *} \\
(0.924)\end{array}$ & & $\begin{array}{c}4.928^{* * *} \\
(1.105)\end{array}$ & \\
\hline Days traded (1 month) & & $\begin{array}{c}-1.482 * * * \\
(0.383)\end{array}$ & & \\
\hline Days traded (2 months) & & & & $\begin{array}{c}-1.355^{* * * *} \\
(0.387)\end{array}$ \\
\hline $\ln$ (issue size) & $\begin{array}{c}0.500 * * * \\
(0.014)\end{array}$ & $\begin{array}{c}0.726^{* * *} \\
(0.196)\end{array}$ & $\begin{array}{c}0.613^{* * *} \\
(0.017)\end{array}$ & $\begin{array}{c}0.817^{* * *} \\
(0.242)\end{array}$ \\
\hline $\ln$ (maturity) & $\begin{array}{c}0.0451^{* * *} \\
(0.009)\end{array}$ & $\begin{array}{c}0.289 * * * \\
(0.028)\end{array}$ & $\begin{array}{c}0.0288^{* * *} \\
(0.010)\end{array}$ & $\begin{array}{c}0.262 * * * \\
(0.025)\end{array}$ \\
\hline Rule 144A & $\begin{array}{c}-0.0721 * * * \\
(0.017)\end{array}$ & $\begin{array}{c}0.261 * * * \\
(0.051)\end{array}$ & $\begin{array}{c}-0.104^{* * *} \\
(0.019)\end{array}$ & $\begin{array}{c}0.228^{* * *} \\
(0.061)\end{array}$ \\
\hline Callable & $\begin{array}{c}0.129^{* * *} \\
(0.043)\end{array}$ & $\begin{array}{l}0.168 * \\
(0.100)\end{array}$ & $\begin{array}{c}0.157^{* * *} \\
(0.049)\end{array}$ & $\begin{array}{l}0.192 * \\
(0.109)\end{array}$ \\
\hline Constant & $\begin{array}{c}-5.253^{* * *} \\
(0.369)\end{array}$ & $\begin{array}{l}-3.586^{*} \\
(1.956)\end{array}$ & $\begin{array}{c}-6.233^{* * *} \\
(0.343)\end{array}$ & $\begin{array}{c}-4.390^{*} \\
(2.370)\end{array}$ \\
\hline $\begin{array}{c}\text { Observations } \\
\mathrm{F}^{\mathrm{EFF}}\end{array}$ & $\begin{array}{l}5283 \\
25.8\end{array}$ & 5283 & $\begin{array}{l}5254 \\
19.9\end{array}$ & 5254 \\
\hline Rating FE & Yes & Yes & Yes & Yes \\
\hline Year FE & Yes & Yes & Yes & Yes \\
\hline
\end{tabular}

13 All results continue to hold using realized trading measures over the three-month post-issuance period. 
Table 4. Cont

\begin{tabular}{|c|c|c|c|c|}
\hline \multirow[t]{2}{*}{ B. Trade Count (Customer Buys) } & \multicolumn{2}{|c|}{ (1) } & \multicolumn{2}{|c|}{ (2) } \\
\hline & 1st stage & 2nd stage & 1st stage & 2nd stage \\
\hline UW centrality & $\begin{array}{c}7.847^{* * *} \\
(1.659)\end{array}$ & & $\begin{array}{l}7.261^{* * *} \\
(1.671)\end{array}$ & \\
\hline Trade count (1 month) & & $\begin{array}{c}-0.887^{* * *} \\
(0.246)\end{array}$ & & \\
\hline Trade count ( 2 months) & & & & $\begin{array}{c}-0.920 * * * \\
(0.271)\end{array}$ \\
\hline $\ln$ (issue size) & $\begin{array}{c}0.952 * * * \\
(0.025)\end{array}$ & $\begin{array}{c}0.829 * * * \\
(0.240)\end{array}$ & $\begin{array}{c}1.006^{* * *} \\
(0.026)\end{array}$ & $\begin{array}{c}0.912^{* * *} \\
(0.280)\end{array}$ \\
\hline $\ln$ (maturity) & $\begin{array}{c}0.212 * * * \\
(0.016)\end{array}$ & $\begin{array}{c}0.410^{* * *} \\
(0.059)\end{array}$ & $\begin{array}{c}0.175^{* * *} \\
(0.016)\end{array}$ & $\begin{array}{c}0.384^{* * *} \\
(0.055)\end{array}$ \\
\hline Rule 144A & $\begin{array}{c}-0.0723 * * \\
(0.031)\end{array}$ & $\begin{array}{c}0.304^{* * *} \\
(0.049)\end{array}$ & $\begin{array}{c}-0.102 * * * \\
(0.032)\end{array}$ & $\begin{array}{c}0.275^{* * *} \\
(0.055)\end{array}$ \\
\hline Callable & $\begin{array}{c}0.291^{* * *} \\
(0.080)\end{array}$ & $\begin{array}{l}0.234 \text { ** } \\
(0.117)\end{array}$ & $\begin{array}{c}0.270 * * * \\
(0.080)\end{array}$ & $\begin{array}{l}0.229 * \\
(0.121)\end{array}$ \\
\hline Constant & $\begin{array}{c}-11.72 * * * \\
(0.629)\end{array}$ & $\begin{array}{c}-6.275^{* *} \\
(2.838)\end{array}$ & $\begin{array}{c}-11.96^{* * *} \\
(0.482)\end{array}$ & $\begin{array}{c}-6.859^{* *} \\
(3.188)\end{array}$ \\
\hline $\begin{array}{c}\text { Observations } \\
\text { F }^{\mathrm{EFF}}\end{array}$ & $\begin{array}{l}5283 \\
22.4\end{array}$ & 5283 & $\begin{array}{l}5254 \\
18.9\end{array}$ & 5254 \\
\hline Rating FE & Yes & Yes & Yes & Yes \\
\hline Year FE & Yes & Yes & Yes & Yes \\
\hline \multirow[t]{2}{*}{ C. Riskless Trade Volume } & \multicolumn{2}{|c|}{ (1) } & \multicolumn{2}{|c|}{ (2) } \\
\hline & 1st stage & 2nd stage & 1st stage & 2nd stage \\
\hline UW centrality & $\begin{array}{c}-1.779 * * * \\
(0.476)\end{array}$ & & $\begin{array}{c}-1.674^{* * *} \\
(0.474)\end{array}$ & \\
\hline Riskless volume (1 month) & & $\begin{array}{c}3.912 * * * \\
(1.227)\end{array}$ & & \\
\hline Riskless volume (2 months) & & & & $\begin{array}{c}3.990 * * * \\
(1.341)\end{array}$ \\
\hline $\ln$ (issue size) & $\begin{array}{c}-0.0457^{* * *} \\
(0.005)\end{array}$ & $\begin{array}{l}0.163 * * \\
(0.064)\end{array}$ & $\begin{array}{c}-0.0543^{* * *} \\
(0.005)\end{array}$ & $\begin{array}{l}0.203^{* *} \\
(0.080)\end{array}$ \\
\hline $\ln$ (maturity) & $\begin{array}{l}0.00544 \\
(0.004)\end{array}$ & $\begin{array}{c}0.200^{* * *} \\
(0.020)\end{array}$ & $\begin{array}{c}0.00237 \\
(0.004)\end{array}$ & $\begin{array}{c}0.214^{* * *} \\
(0.020)\end{array}$ \\
\hline Rule 144A & $\begin{array}{c}0.0391^{* * *} \\
(0.008)\end{array}$ & $\begin{array}{c}0.215^{* * *} \\
(0.064)\end{array}$ & $\begin{array}{c}0.0408^{* * *} \\
(0.008)\end{array}$ & $\begin{array}{c}0.206^{* * *} \\
(0.071)\end{array}$ \\
\hline Callable & $\begin{array}{c}-0.0547^{* * *} \\
(0.019)\end{array}$ & $\begin{array}{l}0.190^{*} \\
(0.114)\end{array}$ & $\begin{array}{c}-0.0541 \text { *** } \\
(0.019)\end{array}$ & $\begin{array}{c}0.196 \\
(0.120)\end{array}$ \\
\hline Constant & $\begin{array}{l}1.468^{* * *} \\
(0.119)\end{array}$ & $\begin{array}{l}-1.422 \\
(1.608)\end{array}$ & $\begin{array}{c}1.340 * * * \\
(0.097)\end{array}$ & $\begin{array}{l}-2.083 \\
(1.913)\end{array}$ \\
\hline $\begin{array}{c}\text { Observations } \\
\text { F EFF }^{\text {EFF }}\end{array}$ & $\begin{array}{l}5283 \\
13.9\end{array}$ & 5283 & $\begin{array}{l}5254 \\
12.5\end{array}$ & 5254 \\
\hline Rating FE & Yes & Yes & Yes & Yes \\
\hline Year FE & Yes & Yes & Yes & Yes \\
\hline
\end{tabular}

The table reports IV regressions in which the dependent variable in the second-stage model is the natural $\log$ of the treasury spread at offering of bonds issued between 2012 and 2017. The endogenous variable of interest is the realized secondary market trading in the one (two) months following the offering date. The instrument is the maximum eigenvector dealer centrality across the dealers in the issue's syndicate based on trading in the calendar year prior to the offering (UW centrality). FEFF is the Montiel Olea and Pflueger (2013) effective first-stage F statistic. All models include credit rating fixed effects and year fixed effects. Standard errors clustered at the issuer level are shown in parentheses. ${ }^{* * *}, * *$, and ${ }^{*}$ indicate coefficients significant at the $1 \%, 5 \%$, and $10 \%$ levels, respectively.

Testing $\pi=0$ is, however, not a robust way to gauge whether an instrument is relevant since conventional methods of inference on $\beta^{\mathrm{IV}}$ are unreliable for $\pi$ in the neighborhood of zero (see Andrews et al. 2019). Instead, we use a formal procedure for detecting weak instruments; an instrument is said to be weak if its correlation with the endogenous regressor is small. To detect weak instruments, we use the Montiel Olea and Pflueger (2013) effective first-stage F-statistic, which Andrews et al. (2019, p. 14) refer to as the "preferred statistic for detecting weak instruments", since it is robust to 
heteroscedasticity, autocorrelation, and clustering. ${ }^{14}$ Weak instruments are those with an effective first-stage F-statistic below $10 .{ }^{15}$ As reported in Table 4, the effective F-statistic $\left(\mathrm{F}^{\mathrm{EFF}}\right)$ exceeds the threshold of 10 for our measures based on days with trades (Panel A), buys from customers (Panel B), and riskless trade volume (Panel C). Therefore, there is strong evidence that underwriter centrality is a relevant instrument.

The primary variable of interest in the second stage regression is the predicted value for realized secondary market trading. From Table 4 Panels A and B, in contrast to the OLS results in Table 3, the coefficient for days traded and trade count in either the one- or two-month period following the offering are strongly negative and significant. From the coefficient estimates, a 10\% increase in expected liquidity implies a decrease in the yield spread at issuance of between $8 \%$ and $14 \%$. Using riskless volume (Panel C) produces a similar interpretation-when dealers are less willing or able to provide liquidity in the secondary market, yield spreads at issuance are greater.

One possible concern with the measures of realized trading activity could be that they may be poorly measured for more actively traded bonds, in particular for riskless volume, for two reasons. The first is that days traded and trade count may be high due to a large number of small trades, while dealers are unwilling or unable to provide liquidity for more significantly sized trades of institutional investors. However, when we re-estimate our models using days traded or trade count based only on trades of 100 bonds or more, our results are nearly identical (not reported for brevity).

Riskless volume presents a different concern: a high incidence of matching buy and sell trades close together in time may simply reflect the rapid arrival of offsetting trades to the dealer. Thus, for more active bonds, high riskless trade volume may not indicate that dealers provide less liquidity. Goldstein and Hotchkiss (2019) show that this alternative interpretation is most relevant for actively traded bonds rated AA and above. In Tables 5-7, we estimate our IV regressions separately for investment grade bonds, high yield bonds (BB+ and below), and bonds rated $\mathrm{BBB}+$ and below (since the largest proportion of newly issued bonds in our sample are initially rated BBB). We report results using a one-month horizon for realized secondary market trading.

As reported in Table 5, the investment grade results for days traded and trade count are consistent with the full-sample IV results. For both days traded and trade count, we reject the weak instrument test as the effective first-stage F-statistics are above 10. Moreover, the second-stage coefficient on realized trade is negative and significant for both trade-based measures, indicating that an increase in liquidity leads to a decrease in the offering yield spread.

14 We use the STATA command weakivtest (Pflueger and Wang (2013)) to estimate the effective first-stage F statistic.

15 As Andrews et al. (2019) note, we must deal with non-orthogonal control variables prior to the construction of the F-statistic. This ensures we measure the incremental effect of our instrument. Montiel Olea and Pflueger (2013) suggest normalizing the dependent variable, the endogenous regressor, and the instrument to be orthogonal to the control variables in the model. The IV model is then estimated using the orthogonalized variables. Per the Frisch-Waugh theorem, the coefficient estimates of the orthogonalized model are identical to those of the IV model in which the control variables are included as additional exogenous regressors. The STATA command weakivtest implements the orthogonalization based on the control variables included in the model prior to estimating the effective first-stage F-statistic. 
Table 5. V Regressions for Offering Yield Spread: Investment Grade Bonds.

\begin{tabular}{lcccccc}
\hline & \multicolumn{2}{c}{$\begin{array}{c}\text { Days traded } \\
\text { (1) }\end{array}$} & \multicolumn{2}{c}{ Trade count } & \multicolumn{2}{c}{ Riskless volume } \\
(2) & & \multicolumn{2}{c}{ (3) } \\
& 1st stage & 2nd stage & 1st stage & 2nd stage & 1st stage & 2nd stage \\
\hline UW centrality & $6.335^{* * *}$ & & $8.949^{* * *}$ & & $-1.800^{* * *}$ \\
& $(1.556)$ & & $(2.689)$ & & $(0.663)$ & \\
Realized trade & & $-1.594^{* * *}$ & & $-1.129^{* * *}$ & & $5.611^{* *}$ \\
& & $(0.512)$ & & $(0.422)$ & & $(2.316)$ \\
ln(issue size) & $0.527^{* * *}$ & $0.838^{* * *}$ & $0.969^{* * *}$ & $1.091^{* * *}$ & $-0.0556^{* * *}$ & $0.310^{* * *}$ \\
& $(0.019)$ & $(0.278)$ & $(0.032)$ & $(0.419)$ & $(0.006)$ & $(0.137)$ \\
ln(maturity) & $0.0410^{* * *}$ & $0.311^{* * *}$ & $0.200^{* * *}$ & $0.472^{* * *}$ & 0.00507 & $0.218^{* * *}$ \\
& $(0.009)$ & $(0.030)$ & $(0.017)$ & $(0.090)$ & $(0.004)$ & $(0.027)$ \\
Rule 144A & $-0.0776^{* * *}$ & $0.321^{* * *}$ & $-0.0840^{* *}$ & $0.350^{* * *}$ & $0.0477^{* * *}$ & 0.177 \\
& $(0.022)$ & $(0.074)$ & $(0.041)$ & $(0.081)$ & $(0.010)$ & $(0.132)$ \\
Callable & $0.140^{* * *}$ & 0.196 & $0.317^{* * *}$ & $0.331^{*}$ & $-0.0625^{* * *}$ & 0.324 \\
& $(0.048)$ & $(0.128)$ & $(0.090)$ & $(0.189)$ & $(0.021)$ & $(0.206)$ \\
Constant & $-5.839^{* * *}$ & $-4.993^{*}$ & $-12.15^{* * *}$ & $-9.445^{*}$ & $1.345^{* * *}$ & -4.603 \\
& $(0.348)$ & $(2.752)$ & $(0.569)$ & $(4.872)$ & $(0.114)$ & $(3.234)$ \\
Observations & & & & & & \\
$F^{E F F}$ & 3898 & 3898 & 3898 & 3898 & 3898 & 3898 \\
CS & 16.58 & & 11.08 & & 7.37 & {$[2.80,20.77]$} \\
Rating FE & & & & & & Yes \\
Year FE & Yes & Yes & Yes & Yes & Yes & Yes \\
\hline
\end{tabular}

The table reports IV regressions in which the dependent variable in the second-stage model is the natural log of the treasury spread at offering of bonds issued between 2012 and 2017. The endogenous variable of interest is the realized secondary market trading in the first month following the offering date. The instrument is the maximum eigenvector dealer centrality across the dealers in the issue's syndicate based on trading in the calendar year prior to the offering (UW centrality). Realized trade refers to days traded (1), trade count (2), and riskless volume (3). FEFF is the Montiel Olea and Pflueger (2013) effective first-stage F statistic. For those models in which FEFF < 10, we report the 95\% Anderson-Rubin confidence set (CSAR). All models include credit rating fixed effects and year fixed effects. Standard errors clustered at the issuer level are shown in parentheses. ${ }^{* * *},{ }^{* *}$, and ${ }^{*}$ indicate coefficients significant at the $1 \%, 5 \%$, and $10 \%$ levels, respectively.

As described above, Goldstein and Hotchkiss (2019) show that riskless volume may be overstated for more actively traded investment grade bonds, so that our results for bonds rated BBB or below may be most informative. Still, we report results using riskless volume for the investment grade subsample, which appear weaker than for the full sample. The first-stage results for riskless volume in Table 5 show that we fail to reject the weak instrument test because the effective F-statistic is only 7.37. Thus, we cannot trust that the second-stage $\beta^{\mathrm{IV}}$ estimate is unbiased. ${ }^{16}$ While there is no consensus in the literature on how to generate an unbiased estimator given weak instruments, weak-instrument robust methods for inference do exist. In the case of just-identified IV models, those in which there is one instrument for each endogenous regressor, Andrews et al. (2019) recommend the Anderson and Rubin (1949) confidence set $\left(\mathrm{CS}_{\mathrm{AR}}\right)$, which provides a robust confidence interval around the true population estimate. Since our model is just identified (one endogenous regressor and one instrument), we estimate a $95 \%$ Anderson-Rubin confidence set for $\beta^{\mathrm{IV}}$ of our riskless volume model. ${ }^{17}$ As shown in Table 5, the true estimate of the relation between riskless volume and offering yield spread lies between 2.80 and 20.77. Hence, although we cannot generate an unbiased estimate of the average effect, the evidence suggests that the average effect is positive and significantly different from zero. A positive effect for riskless volume is consistent with an increase in liquidity leading to a decrease in offering yield.

Lastly, the high-yield (Table 6) and BBB+ and below (Table 7) results paint a similar picture. We reject the weak instrument test for both days traded and trade count and find a negative and significant relation between these two trade-based liquidity measures and offering yield spread. As in the

16 When an instrument is weak, "IV estimates can be badly biased ... and conventional IV confidence intervals may cover the true parameter value far less often than we intend" (Andrews et al. 2019, p. 2).

17 We use the STATA command weakiv (Finlay et al. 2013) to estimate the Anderson-Rubin confidence set. 
investment grade sample, we fail to reject the weak instrument test for riskless volume in either the high-yield or BBB+ and below subsamples. However, we also find that the $95 \%$ Anderson-Rubin confidence set using each subsample indicates that the true effect of riskless volume on offering yield spreads is positive and significant. Thus, the results in Tables 6 and 7 are broadly consistent with our interpretation that yield spreads at issuance are higher when dealers are less expected to provide liquidity in the secondary market.

The conclusion that higher liquidity causes lower offering yield spreads rests on the assumption that our instrument satisfies the exclusion restriction. As previously mentioned, one possible violation of the exclusion restriction is based on the quality of underwriters on the issuer's syndicate. Fang (2005) shows that selection effects exist between underwriter reputation and offering yield spreads. Specifically, the highest reputation underwriters may attract issuers of certain characteristics which are related to borrowing costs. Part of this reputational effect reflects the market making ability of an underwriter, which is precisely what our instrument is intended to capture. If, however, an underwriter's reputation reflects other skills, which are correlated with but distinct from market making, and these skills impact the offering yield spread, then the exclusion restriction of our IV model may not be valid.

Table 6. IV Regressions for Offering Yield Spread: High Yield Bonds.

\begin{tabular}{|c|c|c|c|c|c|c|}
\hline & \multicolumn{2}{|c|}{$\begin{array}{l}\text { Days traded } \\
\text { (1) }\end{array}$} & \multicolumn{2}{|c|}{$\begin{array}{l}\text { Trade count } \\
\text { (2) }\end{array}$} & \multicolumn{2}{|c|}{$\begin{array}{l}\text { Riskless volume } \\
\text { (3) }\end{array}$} \\
\hline & 1st stage & 2nd stage & 1st stage & 2nd stage & 1st stage & 2nd stage \\
\hline UW centrality & $\begin{array}{c}3.065^{* * *} \\
(0.900)\end{array}$ & & $\begin{array}{c}6.460 * * * \\
(1.796)\end{array}$ & & $\begin{array}{c}-1.769 * * * \\
(0.685)\end{array}$ & \\
\hline Realized trade & & $\begin{array}{c}-1.058^{* *} \\
(0.425)\end{array}$ & & $\begin{array}{c}-0.502 * * \\
(0.199)\end{array}$ & & $\begin{array}{l}1.832 * \\
(0.946)\end{array}$ \\
\hline $\ln ($ issue size) & $\begin{array}{c}0.399^{* * *} \\
(0.018)\end{array}$ & $\begin{array}{l}0.371 * * \\
(0.176)\end{array}$ & $\begin{array}{c}0.884^{* * *} \\
(0.030)\end{array}$ & $\begin{array}{c}0.393^{* *} \\
(0.182)\end{array}$ & $\begin{array}{c}-0.0133 \\
(0.011)\end{array}$ & $\begin{array}{c}-0.0266 \\
(0.032)\end{array}$ \\
\hline $\ln$ (maturity) & $\begin{array}{c}0.183^{* * *} \\
(0.036)\end{array}$ & $\begin{array}{l}0.0115 \\
(0.105)\end{array}$ & $\begin{array}{c}0.471 * * * \\
(0.072)\end{array}$ & $\begin{array}{l}0.0544 \\
(0.119)\end{array}$ & $\begin{array}{c}-0.00309 \\
(0.019)\end{array}$ & $\begin{array}{c}-0.176^{* * *} \\
(0.054)\end{array}$ \\
\hline Rule 144A & $\begin{array}{c}-0.0751^{* * *} \\
(0.018)\end{array}$ & $\begin{array}{c}0.0892^{*} \\
(0.048)\end{array}$ & $\begin{array}{c}-0.0576 \\
(0.036)\end{array}$ & $\begin{array}{c}0.140 * * * \\
(0.039)\end{array}$ & $\begin{array}{l}0.0195 \\
(0.013)\end{array}$ & $\begin{array}{c}0.133^{* * *} \\
(0.043)\end{array}$ \\
\hline Callable & $\begin{array}{c}0.029 \\
(0.090)\end{array}$ & $\begin{array}{c}0.219^{* *} \\
(0.106)\end{array}$ & $\begin{array}{l}0.0668 \\
(0.146)\end{array}$ & $\begin{array}{l}0.221^{* *} \\
(0.108)\end{array}$ & $\begin{array}{c}0.000736 \\
(0.026)\end{array}$ & $\begin{array}{l}0.186^{* *} \\
(0.073)\end{array}$ \\
\hline Constant & $\begin{array}{c}-4.258^{* * *} \\
(0.427)\end{array}$ & $\begin{array}{l}3.921^{* *} \\
(1.852)\end{array}$ & $\begin{array}{c}-11.80 * * * \\
(0.705)\end{array}$ & $\begin{array}{c}2.491 \\
(2.382)\end{array}$ & $\begin{array}{c}0.830 * * * \\
(0.220)\end{array}$ & $\begin{array}{c}6.940^{* * *} \\
(0.893)\end{array}$ \\
\hline $\begin{array}{l}\text { Observations } \\
\text { FEFF }^{\text {EFF }}\end{array}$ & $\begin{array}{l}1385 \\
11.59\end{array}$ & 1385 & $\begin{array}{l}1385 \\
12.94\end{array}$ & 1385 & $\begin{array}{r}1385 \\
6.67\end{array}$ & 1385 \\
\hline $\begin{array}{l}\mathrm{CS}_{\mathrm{AR}} \\
\text { Rating FE }\end{array}$ & Yes & Yes & Yes & Yes & Yes & $\begin{array}{c}{[0.54,8.02]} \\
\text { Yes }\end{array}$ \\
\hline Year FE & Yes & Yes & Yes & Yes & Yes & Yes \\
\hline
\end{tabular}

The table reports IV regressions in which the dependent variable in the second-stage model is the natural log of the treasury spread at offering of bonds issued between 2012 and 2017. The endogenous variable of interest is the realized secondary market trading in the first month following the offering date. The instrument is the maximum eigenvector dealer centrality across the dealers in the issue's syndicate based on trading in the calendar year prior to the offering (UW centrality). Realized trade refers to days traded (1), trade count (2), and riskless volume (3). FEFF is the Montiel Olea and Pflueger (2013) effective first-stage F statistic. For those models in which FEFF $<10$, we report the 95\% Anderson-Rubin confidence set (CSAR). All models include credit rating fixed effects and year fixed effects. Standard errors clustered at the issuer level are shown in parentheses. ${ }^{* * *}$, $* *$, and ${ }^{*}$ indicate coefficients significant at the $1 \%, 5 \%$, and $10 \%$ levels, respectively. 
Table 7. IV Regressions for Offering Yield Spread: Bonds rated BBB+ and Below.

\begin{tabular}{lcccccc}
\hline & \multicolumn{2}{c}{$\begin{array}{c}\text { Days traded } \\
\text { (1) }\end{array}$} & \multicolumn{2}{c}{$\begin{array}{c}\text { Trade count } \\
\text { (2) }\end{array}$} & \multicolumn{2}{c}{$\begin{array}{c}\text { Riskless volume } \\
\text { (3) }\end{array}$} \\
\hline & 1st stage & 2nd stage & 1st stage & 2nd stage & 1st stage & 2nd stage \\
\hline UW centrality & $4.932^{* * *}$ & & $10.93^{* * *}$ & & $-1.814^{* * *}$ \\
& $(0.911)$ & & $(1.669)$ & & $(0.603)$ & \\
Realized trade & & $-0.835^{* * *}$ & & $-0.377^{* * *}$ & & $2.270^{* *}$ \\
& & $(0.247)$ & & $(0.104)$ & & $(0.884)$ \\
ln(issue size) & $0.465^{* * *}$ & $0.347^{* * *}$ & $0.911^{* * *}$ & $0.302^{* * *}$ & $-0.0296^{* * *}$ & 0.0258 \\
& $(0.017)$ & $(0.120)$ & $(0.035)$ & $(0.102)$ & $(0.008)$ & $(0.037)$ \\
ln(maturity) & $0.0817^{* * *}$ & $0.248^{* * *}$ & $0.247^{* * *}$ & $0.272^{* * *}$ & -0.000333 & $0.180^{* * *}$ \\
& $(0.014)$ & $(0.028)$ & $(0.024)$ & $(0.032)$ & $(0.006)$ & $(0.021)$ \\
Rule 144A & $-0.0888^{* * *}$ & $0.0901^{* *}$ & $-0.116^{* * *}$ & $0.121^{* * *}$ & $0.03033^{* * *}$ & $0.0955^{* *}$ \\
& $(0.020)$ & $(0.038)$ & $(0.034)$ & $(0.033)$ & $(0.011)$ & $(0.046)$ \\
Callable & 0.0796 & $0.109^{*}$ & $0.230^{* *}$ & $0.129^{* * *}$ & -0.0191 & 0.0855 \\
& $(0.051)$ & $(0.064)$ & $(0.098)$ & $(0.065)$ & $(0.022)$ & $(0.058)$ \\
Constant & $-4.837^{* * *}$ & $1.884^{*}$ & $-11.55^{* * *}$ & 1.552 & $0.974^{* * *}$ & $3.416^{* * *}$ \\
& $(0.290)$ & $(1.071)$ & $(0.552)$ & $(1.120)$ & $(0.131)$ & $(0.828)$ \\
Observations & 3092 & 3092 & 3092 & 3092 & 3092 & 3092 \\
$F^{\text {EFF }}$ & 29.28 & & 42.90 & & 9.06 & {$[1.06,6.51]$} \\
CS & & & & & & Yes \\
Rating FE & Yes & Yes & Yes & Yes & Yes & Yes \\
Year FE & Yes & Yes & Yes & Yes & Yes & \\
\hline
\end{tabular}

The table reports IV regressions in which the dependent variable in the second-stage model is the natural $\log$ of the treasury spread at offering of bonds issued between 2012 and 2017. The endogenous variable of interest is the realized secondary market trading in the first month following the offering date. The instrument is the maximum eigenvector dealer centrality across the dealers in the issue's syndicate based on trading in the calendar year prior to the offering (UW centrality). Realized trade refers to days traded (1), trade count (2), and riskless volume (3). FEFF is the Montiel Olea and Pflueger (2013) effective first-stage F statistic. For those models in which FEFF < 10, we report the 95\% Anderson-Rubin confidence set (CSAR). All models include credit rating fixed effects and year fixed effects. Standard errors clustered at the issuer level are shown in parentheses. ${ }^{* *}, * *$, and ${ }^{*}$ indicate coefficients significant at the $1 \%, 5 \%$, and $10 \%$ levels, respectively.

A potential control for these selection issues is to include underwriter fixed effects in the IV model. This will, however, significantly weaken the power of our instrument as the model will attribute all time-invariant differences between underwriters to the fixed effects. Our instrument is then left to capture only the within-underwriter effect of changes in dealer centrality. In other words, the true effect of an underwriter's market making ability will be split between the fixed effects, which will capture the static component of an underwriter's market making ability, and our instrument, which will capture changes in an underwriter's market making ability during our sample period. ${ }^{18}$ While strengthening the case against a violation of the exclusion restriction, the underwriter fixed effect analysis provides at best a lower bound for the effect of liquidity on offering yield spreads given the loss of power for our instrument.

To implement the underwriter fixed effects model, we add fixed effects for the most active underwriters during our sample period. We identify the top 20 underwriters as those with the highest aggregate primary market trade volume across all offerings in our sample. ${ }^{19}$ We then create an indicator for each of these 20 dealers if, for a given bond offering, that dealer appears as a member of the syndicate based on their primary market trades reported to TRACE.

18 For some perspective on the magnitudes of between-underwriter and within-underwriter variation in dealer centrality, we analyze the distribution of our dealer centrality measure for the 159 dealers that serve on a syndicate in our sample. For each dealer, we calculate the standard deviation of its centrality during the sample period. This provides an estimate of the level of within-dealer variation. For each dealer, we also calculate its mean centrality over the sample period. We then calculate the standard deviation of these mean values across all the syndicate dealers in our sample. This provides an estimate of the level of between-dealer variation. Based on these estimates, the ratio of between-underwriter variation to within-underwriter variation is over eight. This indicates the between-underwriter variation is almost an order of magnitude larger than the within-underwriter variation.

19 The top 20 appears as a natural break-point in the distribution of primary market volume across dealers. 
Our IV regressions, augmented to include the dummy variables for the top 20 underwriters, are reported in Table 8. In all three specifications, we fail to reject the weak instrument test since the effective first-stage F-statistics are all below 10. Thus, given underwriter fixed effects, underwriter centrality no longer has enough incremental explanatory power to satisfy the weak instrument test. This is not surprising, since underwriter centrality is relatively static during our sample period for most dealers. As previously discussed, we can use Anderson-Rubin confidence sets to establish bounds for the effect of liquidity on offering yield spreads even though we are unable to establish an unbiased estimate. As shown in Table 8, for both days traded and trade count, the 95\% Anderson-Rubin confidence set implies that the effect of each measure is negative and significant. This is consistent with the days traded and trade count estimates throughout our analysis and provides further evidence that an increase in liquidity causes a decrease in offering yield spreads.

Table 8. IV Regressions for Offering Yield Spread Including Underwriter Fixed Effects.

\begin{tabular}{|c|c|c|c|c|c|c|}
\hline & \multicolumn{2}{|c|}{$\begin{array}{c}\text { Days traded } \\
\text { (1) }\end{array}$} & \multicolumn{2}{|c|}{$\begin{array}{l}\text { Trade count } \\
\text { (2) }\end{array}$} & \multicolumn{2}{|c|}{$\begin{array}{c}\text { Riskless volume } \\
\text { (3) }\end{array}$} \\
\hline & 1st stage & 2nd stage & 1st stage & 2nd stage & 1st stage & 2nd stage \\
\hline UW centrality & $\begin{array}{c}3.472^{* * *} \\
(1.149)\end{array}$ & & $\begin{array}{l}5.571^{* * *} \\
(1.964)\end{array}$ & & $\begin{array}{c}-1.290 * * \\
(0.644)\end{array}$ & \\
\hline Realized trade & & $\begin{array}{c}-1.225^{* *} \\
(0.585)\end{array}$ & & $\begin{array}{c}-0.763 * * \\
(0.387)\end{array}$ & & $\begin{array}{l}3.296 * \\
(1.900)\end{array}$ \\
\hline $\ln$ (issue size) & $\begin{array}{c}0.480 * * * \\
(0.014)\end{array}$ & $\begin{array}{l}0.596^{* *} \\
(0.283)\end{array}$ & $\begin{array}{l}0.916^{* * *} \\
(0.026)\end{array}$ & $\begin{array}{l}0.707^{* *} \\
(0.357)\end{array}$ & $\begin{array}{c}-0.0448^{* * *} \\
(0.006)\end{array}$ & $\begin{array}{l}0.156 * \\
(0.088)\end{array}$ \\
\hline $\ln$ (maturity) & $\begin{array}{c}0.0488^{* * *} \\
(0.009)\end{array}$ & $\begin{array}{c}0.284^{* * *} \\
(0.035)\end{array}$ & $\begin{array}{c}0.218^{* * *} \\
(0.016)\end{array}$ & $\begin{array}{c}0.390^{* * *} \\
(0.088)\end{array}$ & $\begin{array}{c}0.00529 \\
(0.004)\end{array}$ & $\begin{array}{c}0.206^{* * *} \\
(0.020)\end{array}$ \\
\hline Rule 144A & $\begin{array}{c}-0.0630^{* * *} \\
(0.017)\end{array}$ & $\begin{array}{l}0.261^{* * *} \\
(0.053)\end{array}$ & $\begin{array}{c}-0.0527 * \\
(0.031)\end{array}$ & $\begin{array}{l}0.298 * * * \\
(0.046)\end{array}$ & $\begin{array}{c}0.0377^{* * *} \\
(0.008)\end{array}$ & $\begin{array}{c}0.214^{* * *} \\
(0.081)\end{array}$ \\
\hline Callable & $\begin{array}{c}0.122 * * * \\
(0.042)\end{array}$ & $\begin{array}{c}0.141 \\
(0.105)\end{array}$ & $\begin{array}{l}0.272^{* * *} \\
(0.084)\end{array}$ & $\begin{array}{c}0.199 \\
(0.139)\end{array}$ & $\begin{array}{c}-0.0497^{* * *} \\
(0.019)\end{array}$ & $\begin{array}{c}0.155 \\
(0.126)\end{array}$ \\
\hline Constant & $\begin{array}{c}-4.968^{* * *} \\
(0.364)\end{array}$ & $\begin{array}{l}-2.339 \\
(2.775)\end{array}$ & $\begin{array}{c}-11.22 * * * \\
(0.621)\end{array}$ & $\begin{array}{l}-4.878 \\
(4.233)\end{array}$ & $\begin{array}{c}1.431^{* * *} \\
(0.125)\end{array}$ & $\begin{array}{c}-0.88 \\
(2.415)\end{array}$ \\
\hline $\begin{array}{l}\text { Observations } \\
\text { F }^{\text {EFF }}\end{array}$ & $\begin{array}{c}5283 \\
9.13\end{array}$ & 5283 & $\begin{array}{l}5283 \\
8.04\end{array}$ & 5283 & $\begin{array}{l}5283 \\
4.02\end{array}$ & 5283 \\
\hline $\mathrm{CS}_{\mathrm{AR}}$ & & {$[-3.99,-0.41]$} & & {$[-2.86,-0.25]$} & & {$[1.20, \infty]$} \\
\hline $\begin{array}{l}\text { Top underwriter } \\
\text { FE }\end{array}$ & Yes & Yes & Yes & Yes & Yes & Yes \\
\hline Rating FE & Yes & Yes & Yes & Yes & Yes & Yes \\
\hline Year FE & Yes & Yes & Yes & Yes & Yes & Yes \\
\hline
\end{tabular}

The table reports IV regressions in which the dependent variable in the second-stage model is the natural log of the treasury spread at offering of bonds issued between 2012 and 2017. The endogenous variable of interest is the realized secondary market trading in the first month following the offering date. The instrument is the maximum eigenvector dealer centrality across the dealers in the issue's syndicate based on trading in the calendar year prior to the offering (UW centrality). Realized trade refers to days traded (1), trade count (2), and riskless volume (3). FEFF is the Montiel Olea and Pflueger (2013) effective first-stage F statistic. For those models in which FEFF < 10, we report the $95 \%$ Anderson-Rubin confidence set (CSAR). All models include fixed effects for the top 20 underwriters, credit rating fixed effects, and year fixed effects. Standard errors clustered at the issuer level are shown in parentheses. ${ }^{* * *}$, **, and ${ }^{*}$ indicate coefficients significant at the $1 \%, 5 \%$, and $10 \%$ levels, respectively.

Table 8 also shows that results using underwriter fixed effects with riskless volume are too weak to yield much of a conclusion. As Andrews et al. (2019) note, when the first stage is not distinguishable from zero, the $\mathrm{CS}_{\mathrm{AR}}$ can be infinite- that is exactly what we find. Thus, after we control for underwriter fixed effects, there is not enough variation left in underwriter centrality to analyze riskless volume.

Underwriter fixed effects capture the average quality of each of the top 20 underwriters over our sample period. If the quality of individual underwriters does not vary much during this time period, then the inclusion of the fixed effects will adequately control for the effect of underwriter quality on offering yield spreads. If, however, underwriter quality varies over time, then our approach may understate the underwriter selection effects. To further mitigate the concern that underwriter quality leads to a violation of the exclusion restriction, we estimate our IV models with separate underwriter fixed effects for the first and second halves of our sample period. This allows for some evolution 
in underwriter quality. The results, unreported for brevity, are almost identical to those reported in Table 8, hence assuming time invariant underwriter effects appears reasonable.

Overall, based on inclusion of underwriter fixed effects and various subsamples of our data, we continue to find evidence that an increase in expected liquidity leads to lower borrowing costs at least when using days traded and trade count to measure liquidity. Using granular fixed effects sets a high bar on these results given that underwriter quality appears fairly constant within our sample and subsample periods. Still, these results, as well as those for subsamples by time periods and by issuer rating quality, provide useful analysis of the robustness of our results to a potential violation of the exclusion restriction.

\section{Conclusions}

This paper studies the link between secondary market liquidity for a corporate bond and the bond's yield spread at issuance. Using several measures of realized secondary market trading, we find that expected liquidity of a bond at issuance has an economically large impact on the cost of raising funds. We develop measures of expected liquidity based on the pre-issuance network centrality for underwriters of the bond. We estimate that a $10 \%$ increase in expected liquidity implies a decrease in the yield spread at issuance of between $8 \%$ and $14 \%$.

Our results suggest that expected after-market liquidity for corporate bonds can significantly lower issuers' cost of capital. When the ability of dealers to provide aftermarket liquidity to the issues they underwrite is impaired, the cost to firms attempting to raise capital should be expected to increase substantially. Our results also contribute more generally to the literature which examines the impact of liquidity on asset prices.

Author Contributions: All authors contributed equally to the main text.

Funding: This research received no external funding.

Acknowledgments: David Pedersen acknowledges partial financial support from the David Whitcomb Center for Research in Financial Services of Rutgers University.

Conflicts of Interest: The authors declare no conflict of interest.

\section{References}

Acharya, Viral, and Lasse Pedersen. 2005. Asset pricing with liquidity risk. Journal of Financial Economics 77: 375-410. [CrossRef]

Amihud, Yakov. 2002. Illiquidity and stock returns: Cross-section and time-series effects. Journal of Financial Markets 5: 31-56. [CrossRef]

Amihud, Yakov, and Haim Mendelson. 1986. Asset pricing and the bid-ask spread. Journal of Financial Economics 17: 223-49. [CrossRef]

Anderson, Theodore, and Herman Rubin. 1949. Estimators for the parameters of a single equation in a complete set of stochastic equations. Annals of Mathematical Statistics 21: 570-82.

Andrews, Isaiah, James Stock, and Liyang Sun. 2019. Weak instruments in IV regression: Theory and practice. Annual Review of Economics. Unpublished working paper.

Bao, Jack, Jun Pan, and Jiang Wang. 2011. The illiquidity of corporate bonds. Journal of Finance 66: 911-46. [CrossRef]

Benveniste, Lawrence, and Manoj Singh. 1993. The failure of Drexel Burnham Lambert: Evidence on the implications for commercial banks. Journal of Financial Intermediation 3: 104-37. [CrossRef]

Brugler, James, Carole Comerton-Forde, and J. Spencer Martin. 2018. Do you see what I see? Transparency and bond issuing costs. Working Paper, Carlton, VIC, Australia: University of Melbourne and UNSW Business School.

Cai, Nianyun, Jean Helwege, and Arthur Warga. 2007. Underpricing in the Corporate Bond Market. The Review of Financial Studies 20: 2021-46. [CrossRef]

Chen, Long, David A. Lesmond, and Jason Wei. 2007. Corporate yield spreads and bond liquidity. Journal of Finance 62: 119-49. [CrossRef] 
Datta, Sudip, Mai Iskandar-Datta, and Ajay Patel. 1997. The pricing of initial public offers of corporate straight debt. Journal of Finance 52: 379-96. [CrossRef]

Datta, Sudip, Mai Iskandar-Datta, and Ajay Patel. 2000. Some evidence on the uniqueness of initial public debt offerings. Journal of Finance 55: 715-43. [CrossRef]

Di Maggio, Marco, Amir Kermani, and Zhaogang Song. 2017. The value of trading relationships in turbulent times. Journal of Financial Economics 124: 266-84. [CrossRef]

Dick-Nielsen, Jens, Peter Feldhütter, and David Lando. 2012. Corporate bond liquidity before and after the onset of the subprime crisis. Journal of Financial Economics 103: 471-92. [CrossRef]

Ederington, Louis, Wei Guan, and Pradeep Yadav. 2014. Dealer spreads in the corporate bond market: Agent vs. market-making roles. Working Paper, Norman, OK, USA: University of Oklahoma.

Ellul, Andrew, and Marco Pagano. 2006. IPO Underpricing and After-Market Liquidity. Review of Financial Studies 19: 381-421. [CrossRef]

Fang, Lily. 2005. Investment bank reputation and the price and quality of underwriting services. Journal of Finance 60: 2729-761. [CrossRef]

Field, Laura, Anahit Mkrtchyan, and Yuan Wang. 2018. Bond liquidity and investment. Working Paper, Newark, DE, USA: University of Delaware, Boston, MA, USA: Northeastern University, Montreal, QC, Canada: Concordia University.

Finlay, Keith, Leandro Magnusson, and Mark Shaffer. 2013. WEAKIV: Weak-Instrument-Robust Tests and Confidence Intervals for Instrumental-Variable (IV) Estimation of Linear, Probit and Tobit Models. Available online: http://ideas.repec.org/c/boc/bocode/s457684.html (accessed on 7 May 2019).

Flanagan, Thomas, Simi Kedia, and Xing Zhou. 2019. Primary Market Allocations in Corporate Bonds: Trading Ties and Secondary Market Liquidity. Working Paper, Ann Arbor, MI, USA: University of Michigan, Newark, NJ, USA: Rutgers University, Washington, DC, USA: Federal Reserve Board of Governors.

Goldstein, Michael A., and Edith S. Hotchkiss. 2012. Dealer Behavior and the Trading of Newly Issued Corporate Bonds. Working Paper, Babson Park, MA, USA: Babson College, Chestnut Hill, MA, USA: Boston College.

Goldstein, Michael A., Edith S. Hotchkiss, and Erik R. Sirri. 2007. Transparency and liquidity: A controlled experiment on corporate bonds. Review of Financial Studies 20: 235-73. [CrossRef]

Goldstein, Michael A., and Edith S. Hotchkiss. 2019. Providing liquidity in an illiquid market: Dealer behavior in U.S. corporate bonds. Journal of Financial Economics. Unpublished working paper. [CrossRef]

Harris, Lawrence. 2015. Transactions costs, trade throughs, and riskless principal trading in corporate bond markets. Working Paper, Los Angeles, CA, USA: University of Southern California.

Helwege, Jean, and Liying Wang. 2017. Liquidity and price pressure in the corporate bond market: Evidence from mega-bonds. Working Paper, Riverside, CA, USA: UC Riverside, Lincoln, NE, USA: University of Nebraska at Lincoln.

Hollifield, Burton, Artem Neklyudov, and Chester Spatt. 2017. Bid-ask spreads, trading networks and the pricing of securitizations. Review of Financial Studies 30: 3048-85. [CrossRef]

Johnson, Timothy. 2008. Volume, liquidity, and liquidity risk. Journal of Financial Economics 87: 388-417. [CrossRef]

Lemmon, Michael, and Michael Roberts. 2010. The Response of Corporate Financing and Investment to Changes in the Supply of Credit. Journal of Financial and Quantitative Analysis 45: 555-87. [CrossRef]

Li, Dan, and Norman Schürhoff. 2019. Dealer networks. Journal of Finance 74: 91-144. [CrossRef]

Montiel Olea, Jose Luis, and Carolin Pflueger. 2013. A robust test for weak instruments. Journal of Business and Economic Statistics 31: 358-69. [CrossRef]

Nagler, Florian, and Giorgio Ottonello. 2018. Structural changes in corporate bond underpricing. Working Paper, Milan, Italy: BAFFI CAREFIN Centre.

Nashikkar, Amrut, Marti G. Subrahmanyam, and Sriketan Mahanti. 2011. Liquidity and arbitrage in the market for credit risk. Journal of Financial and Quantitative Analysis 46: 627-56. [CrossRef]

Nikolova, Stanislava, Liying Wang, and Julie Wu. 2019. Institutional Allocations in the Primary Market for Corporate Bonds. Working Paper, Lincoln, NE, USA: University of Nebraska at Lincoln.

Pflueger, Carolin, and Su Wang. 2013. WEAKIVTEST: Stata Module to Perform Weak Instrument Test for a Single Endogenous Regressor in TSLS and LIML. Statistical Software Components S457732. Chestnut Hill: Boston College Department of Economics, revised 9 September 2018.

Schultz, Paul. 2017. Inventory management by corporate bond dealers. Working Paper, Notre Dame, IN, USA: University of Notre Dame. 
Scribney, William, Vince Wiggins, and David Drukker. 2019. Negative and missing R-squared for 2SLS/IV, Stata Corp. Available online: https://www.stata.com/support/faqs/statistics/two-stage-least-squares/ (accessed on 15 March 2019).

Sirri, Erik. 2014. Report on secondary market trading in the municipal securities market. Working Paper, Washington, DC, USA: Municipal Securities Rulemaking Board.

Zitzewitz, Eric. 2010. Paired corporate bond trades. Working Paper, Hanover, NH, USA: Dartmouth College.

(). (1) (C) 2019 by the authors. Licensee MDPI, Basel, Switzerland. This article is an open access article distributed under the terms and conditions of the Creative Commons Attribution (CC BY) license (http://creativecommons.org/licenses/by/4.0/). 